Syntax Literate: Jurnal Ilmiah Indonesia p-ISSN: 2541-0849

e-ISSN: 2548-1398

Vol. 6, No. 2, Februari 2021

\title{
ANALISA BALOK DENGAN PERKUATAN PENAMBAHAN TULANGAN MEMAKAI PEREKAT SIKADUR DAN ANCHOR FIX-2 SECARA EXPERIMENTAL
}

\author{
Andar Sitohang, Johannes Tarigan dan Medis Surbakti \\ Universitas Sumatera Utara, Indonesia \\ Email: sitohanga@gmail.com, johannes_tarigan@yahoo.com dan \\ medissurbakti@yahoo.com
}

\begin{abstract}
This research was conducted to determine the analytical and experimental load increase with the addition of D10 $\mathrm{mm}$ threaded iron reinforcement and to compare the epoxial adhesion (Sikadur 31 CF Normal and Anchor Fix 2 Normal). Tests were carried out on 3 (three) $10 \times 15 \times 150 \mathrm{~cm}$ reinforced concrete beam specimens divided into 3 (three) groups, namely normal reinforced concrete beams and reinforced concrete beams with reinforced D10 $\mathrm{mm}$ iron screw coated with Sikadur 31 CF Normal and Anchor Fix 2 Normal. Furthermore, the test object is given a centralized load until the reinforced concrete beams collapse so that the maximum load and deflection are known. The results showed that the addition of D10 mm thread iron with 31 CF Normal sikadur adhesive was able to increase the flexural strength by $37.78 \%$ from the initial strength while using Anchor fix 2 adhesive was able to increase the flexural strength by $30 \%$ from the initial strength. Based on theoretical analysis and test results proved that the addition of external strengthening of iron thread D10 $\mathrm{mm}$ using adhesive is able to increase the ability of beams in carrying bending much better than normal conditions.
\end{abstract}

Keywords: flexural strength of reinforced beam; d10 mm iron; sikadur; anchor fix 2

\begin{abstract}
Penelitian ini dilakukan untuk mengetahui peningkatan beban secara analitis dan experimental dengan penambahan perkuatan besi ulir d10 $\mathrm{mm}$ dan membandingkan daya rekat epoxsi (sikadur $31 \mathrm{CF}$ normal dan anchor fix 2 normal). Pengujian dilakukan terhadap 3 (tiga) buah benda uji balok beton bertulang ukuran 10 x $15 \mathrm{x}$ $150 \mathrm{~cm}$ yang dibagi kedalam 3 (tiga) kelompok yaitu balok beton bertulang normal dan balok beton bertulang dengan perkuatan besi ulir D10 mm yang dilapisi Sikadur $31 \mathrm{CF}$ normal dan achor fix 2 normal. Selanjutnya benda uji diberikan beban terpusat sampai balok beton bertulang runtuh sehingga diketahui beban maxsimum dan lendutannya. Hasil penelitian menunjukkan bahwa penambahan besi ulir D10 mm dengan perekat Sikadur 31 CF normal mampu meningkatkan kuat lentur sebesar $37,78 \%$ dari kekuatan awalnya sedangan memakai perekat anchor fix 2 mampu meningkatkan kuat lentur sebesar 30\% dari kekuatan awalnya. Berdasarkan analisa secara teoritis maupun hasil pengujian terbukti bahwa penambahan perkuatan eksternal besi ulir D10 mm memakai perekat mampu meningkatkan kemampuan balok dalam memikul lentur jauh lebih baik dari kondisi normalnya.
\end{abstract}


Kata kunci: kuat lentur balok bertulang; besi d10 mm; sikadur; anchor fix 2

\section{Coresponden Author}

Email: sitohanga@gmail.com Artikel dengan akses terbuka dibawah lisensi

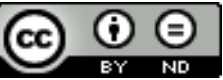

\section{Pendahuluan}

Balok merupakan elemen lentur yang mempunyai karakteristik internal yang lebih rumit dalam memikul beban dibandingkan dengan jenis elemen struktur yang lainnya. Konstruksi balok dengan balok beton bertulang dimaksudkan agar dapat melengkapi kelemahan dari material-material pembentuknya. Kelebihan utama yang dimiliki oleh beton bertulang adalah kombinasi beton dan baja tulangan yang memberikan kuat tekan sekaligus kuat tarik yang besar.

Suatu struktur dengan desain tertentu akan mampu memikul beban yang sesuai dengan perencanaan. Jika suatu struktur memikul beban yang berlebihan (tidak sesuai dengan perencanaan), maka struktur tersebut akan mengalami lendutan yang berlebihan dari kemampuan struktur tersebut, yang mengakibatkan terjadinya retak/patahan pada struktur tersebut, maka struktur tersebut perlu solusi perbaikan untuk mengembalikan kekuatan pikulnya.

Penelitian-penelitian sebelumnya yang berhubungan dengan perbaikan struktur dengan menambahkan perkuatan sudah banyak dilakukan oleh banyak peneliti diantaranya: Perbaikan balok beton bertulang yang telah mengalami beban puncak dengan baja siku (Helmi, 2009). Penggunaan CFRP sebagai bahan komposit eksenternal pada struktur balok beton bertulang (Pangestuti, 2009). Pengaruh lapisan hybrid serat karbon dan serat gelas terhadap kapasitas lentur balok bertulang (Djamaluddin, Irmawati, \& Didipu, 2014). Perbandingan kekuatan lentur balok beton bertulang dengan menggunakan perkuatan CFRP dan GFRP (Ginardi, Anggraini, \& Suseno, 2014). Tinjauan variasi tebal grouting sikadur $31 \mathrm{CF}$ normal dan panjang penyaluran terhadap daya lekat baja tulangan pada beton mutu normal (Rosyidah \& Yasin, 2011). Analisis retak lentur pada balok beton bertulang mutu tinggi yang diperbaiki dengan injeksi epoxy (Puspita, Aulia, \& Afifuddin, 2018). Perilaku Runtuh Balok Beton Bertulang yang Diperkuat dengan Lapis Glass Fibre Reinforced Polymer (Gfrp) (Sudarsana \& Widiarsa, 2008). Pengaruh Penggunaan Carbon Fibre Sheet terhadap Kekakuan Pada Balok Beton Bertulang (Mulyadi, 2018). Pengaruh Pembalutan Carbon Fiber Wrap (Cfw) terhadap Daktilitas Balok Beton Bertulang (Utami, Nuroji, \& Antonius, 2016). Kerusakan dan Perkuatan Struktur Beton Bertulang (Isneini, 2009). Analisa Balok Beton Bertulang Cold Formed Menggunakan Solidworks (Jaya, 2014). Studi Perkuatan Balok Beton Bertulang Dengan Strand Tanpa Penegangan dan Tulangan U (Susanto, Kasyanto, \& Susilahadi, 2018). Penggunaan Carbon Fiber Reinforced Plate sebagai Tulangan Eksternal pada Struktur Balok Beton (Pangestuti, 2009). Perilaku Lentur 
Perbaikan Balok Beton Bertulang dengan Variasi Lebar Carbon Fibre Reinforced Polymer (Jamal, Bale, \& Haqiqi, 2015). Kajian Eksperimental Perilaku Balok Beton Tulangan Tunggal Berdasarkan Tipe Keruntuhan Balok (Nur, 2009).

Namun saat ini, telah muncul inovasi baru dalam perencanaan struktur bangunan dalam peningkatan perkuatan struktur beton, diantaranya dengan penambahan lapisan FRP (fiber reinforced polymer), plat baja termasuk penambahan besi beton dan lainlain. Salah satu usaha untuk meningkatkan kekuatan dan daktilitas balok beton bertulang adalah menambahkan besi ulir D10 mm dibagian tekan balok dengan menggunakan jenis perekat Sikadur $31 \mathrm{CF}$ normal dan anchor fix 2. Diharapkan penelitian ini akan memberikan konstribusi terhadap peningkatan kekuatan beton struktur tersebut.

Adapun tujuan dari penelitian ini adalah:

1. Mengetahui peningkatan beban perkuatan secara analitis dan experimental dengan penambahan bahan besi ulir pada balok beton bertulang yang telah dibebani hingga tulangan meleleh.

2. Membandingkan sifat bond dari jenis perekat (sikadur $31 \mathrm{CF}$ normal dan anchor fix2 normal). Manakah yang memiliki dampak peningkatan paling signifikan terhadap kuat lentur balok beton.

3. Mengetahui pola retakan dan model keruntuhan balok dengan 3 variabel (beton normal, beton perkuatan besi ulir D10 mm memakai perekat Sikadur 31 CF normal dan perkuatan besi ulir D10 mm memakai anchor Fix 2 normal.

\section{Metode Penelitian}

1. Tahapan Penelitian

Dalam penelitian ini, sampel terdiri dari 3 (tiga) benda uji silinder dengan ukuran diameter $15 \mathrm{~cm}$ dam tinggi $30 \mathrm{~cm}$ untuk pengujian kuat tekan beton, dan 3 (tiga) benda uji balok ukuran10x15x150 cm untuk pengujian lentur dengan mutu beton rencana f'c $25 \mathrm{MPa}$ dimana satu balok beton beton bertulang tanpa perkuatan dan satu balok beton bertulang denganmenggunakan perkuatan besi ulir dengan memakai perekat (Sikadur 31 normal dan anchor fix 2 normal). Balok diuji pada saat umur beton 28 hari.

2. Syarat-Syarat Pelaksanaan

Dalam pengujian kuat lentur suatu balok beton, hal yang terutama diperhatikan adalah perencanaan campuran beton, dan merencanakan kekuatan suatu balok. Sehingga sangat diperlukan ketelitian dalam merencanakan pembuatan benda uji balok, baik dari segi hitungan kekuatan beton dan baja tulangan maupun dari segi pelaksanaan pengerjaan benda uji. Jika dalam pelaksanaan terjadi kesalahan, maka hasil yang akan dicapai dalam pengujian kekuatan suatu balok tidak tercapai.

Untuk mencapai hasil seperti yang direncanakan, maka diperlukan beberapa kriteria yang harus diperhatikan yaitu; 


\section{Perencanaan Campuran Beton}

Beton merupakan suatu material yang diperoleh dari campuran yang mempunyai proporsi tertentu dari semen, agregat halus (pasir), agregat kasar (kerikil) dan air. Beton dalam berbagai variasi kekuatan dapat diperoleh dengan perencanaan yang sesuai dari perbandingan jumlah material pembentuknya. Dalam pengujian ini, untuk membentuk kekuatan beton yang direncanakan (mutu beton $\mathrm{K}_{250}$ ) dilakukan pemeriksaan sifat-sifat fisis agregat dan perencanaan perbandingan campuran beton (mix design).

Dalam proses pengecoran perlu diperhatikan nilai slump test. Di mana tujuan slump test adalah untuk memeriksa kekentalan dari campuran beton apakah sesuai dengan nilai slump (kekentalan) yang direncanakan. Untuk menjaga adukan beton tidak terlalu encer dan kental dianjurkan untuk menggunakan nilai-nilai slump yang ditunjukan dalam peraturan di dalam pelaksanaan pengeringan beton.

2. Baja Tulangan

Ada dua jenis tulangan yaitu tulangan polos dan tulangan ulir. Jenis tulangan yang dipakai adalah tulangan ulir. Pada penelitian ini, digunakan tulangan ulir D13 mm, sebagai tulangan tarik. Sedangkan untuk sengkang digunakan baja tulangan $\phi 6 \mathrm{~mm}$ yang berfungsi sebagai pengikat antar tulangan. Untuk memastikan mutu baja tulangan ini sesuai dengan mutu baja yang diharapkan, maka dilakukan pengujian kuat tarik baja tulangan. Hal ini dilakukan supaya mendapatkan hasil yang direncanakan dalam balok beton.

3. Resin Epoxy

Mengingat kekuatan lekatan antara tulangan dan beton merupakan salah satu faktor mempengaruhi kekuatan tarik tulangan pada struktur beton bertulang, sedangkan tulangan yang dipasang pada beton dilakukan setelah beton menjadi keras, maka perlu suatu zat untuk melekatkan antara baja tulangan dengan beton. Zat yang digunakan adalah zat epoxy yang bagus sebagai perekat dan coating. Dalam penelitian ini digunakan zat perekat jenis sikadur $31 \mathrm{CF}$ normal dan anchor fix 2 normal. Dimana sikadur $31 \mathrm{CF}$ normal mempunyai kuat lekat (bond strength) epoxyjenis ini mencapai $20 \mathrm{~N} / \mathrm{mm}$ setelah 7 hari dioleskan pada beton yang sudah mencapai umur 28 hari.

4. Pembuatan Benda Uji

Benda uji berupa balok beton bertulang dengan ukuran 100 x 150x $1500 \mathrm{~mm}$ dengan tebal selimut beton $20 \mathrm{~mm}$. Tulangan yang dipakai adalah tulangan tarik 2D13 mm dan tulangan tekan 3D13 mm dengan fy = 340.21 MPa dan sengkang $\phi 6$ dengan jarak $15 \mathrm{~mm}$. Campuran beton direncanakan dengan f'c $=21,34 \mathrm{MPa}$ dengan ukuran agregat kasar maksimum $20 \mathrm{~mm}$. Percobaan dibuat dalam 3 perlakuan yaitu balok tanpa perkuatan (sebagai balok kontrol), balok dengan penambahan besi ulir 3D10 mm memakai perekat Sikadur $31 \mathrm{CF}$ normal dan balok dengan penambahan besi ulir 3D10 mm memakai perekat anchor fix 2 normal. Setiap perlakuan dibuat 1 benda uji. Untuk lebih jelas lihat. 
Tabel 1

Benda Uji

\begin{tabular}{cccc}
\hline Nama & $\begin{array}{c}\text { Jumlah } \\
\text { Pengujian }\end{array}$ & $\begin{array}{c}\text { Jumlah } \\
\text { Penambahan Besi } \\
\text { D10 mm }\end{array}$ & Perekat \\
\hline Beton I & 1 & - & \\
\hline Beton II & 1 & $3 \mathrm{D} 10 \mathrm{~mm}$ & $\begin{array}{c}\text { Sicadur 31 CF } \\
\text { Normal }\end{array}$ \\
\hline Beton III & 1 & $3 \mathrm{D} 10 \mathrm{~mm}$ & $\begin{array}{c}\text { Anchor fix 2 } \\
\text { Normal }\end{array}$ \\
\hline
\end{tabular}

5. Pemasangan Besi Ulir Dengan Perekat Sikadur 31CF Normal dan Anchor fix 2 Normal

Penambahan tulangan besi ulir 3D10 mm dilakukan setelah beton berumur 28hari. Permukaan balok beton bagian bawah dikorek dengan greaneda machine, sepanjang $140 \mathrm{~cm}$ dengan lebar $15 \mathrm{~mm}$ lalu dibersihkan, sebagai perekat antara besi dengan balok beton digunakan Sikadur 31 CF normal, Sikadur 31 CF normal terdapat 2 campuran, yaitu komponen A dan komponen B. Cara pemakaiannya dengan mencampur kedua komponen $\mathrm{A}+\mathrm{B}$ dengan memakai bor listrik dengan putaran rendah sampai material tercampur rata dan berwarna abu-abu. Setelah campuran sikadur merata, tuangkan pada bagian permukaan balok yang sudah dikorek dan juga pada besi ulir secara merata. Pengujian dilakukan setelah lem epoksi atau Sikadur $31 \mathrm{CF}$ normal tersebut benar-benar dalam keadaan kering. Berdasarkan prosedur pemakaian, Sikadur akan mengering dalam waktu 1 (satu) hari, kemudian benda uji tersebut dapat diuji. Sedangkan pemakaian benda uji dengan anchor fix 2 (dua) normal hampir sama dengan diatas, dimana permukaan balok beton bagian bawah dikorek dengan greaneda machine, sepanjang $140 \mathrm{~cm}$ dengan lebar $15 \mathrm{~mm}$ lalu bersihkan. Suntikkan perekat ke dalam lubang, mulai dari bagian bawah. Dalam hal apapun hindari udara yang menjebak. Setelah campuran merata lalu masukkan besi ulir D10 mm dengan gerakan memutar ke dalam lubang yang telah disediakan. Beberapa perekat harus keluar dari lubang itu. Berdasarkan prosedur pemakaian anchor fix 2 normal akan mengering dalam waktu 7 hari, kemudian benda uji tersebut dapat diuji.

6. Uji Pembebanan

Pengujian balok dilakukan dengan meletakkan balok di atas 2 tumpuan sederhana dan dibebani 2 beban terpusat dengan jarak $450 \mathrm{~mm}$ dari masingmasing tumpuan. Pembebanan dilakukan secara bertahap sampai balok dianggap runtuh. Uji pembebanan dilakukan setelah beton berumur 28 hari. +7 hari setelah penambahan perkuatan besi ulir D10 mm. Dial Grauge (alat pengukur lendutan/penurunan) di letakkan di bawah balok dengan posisi di tiga titik, yakni 1/4 L-L, 1/L (Center line) dan 1/4L-R. 

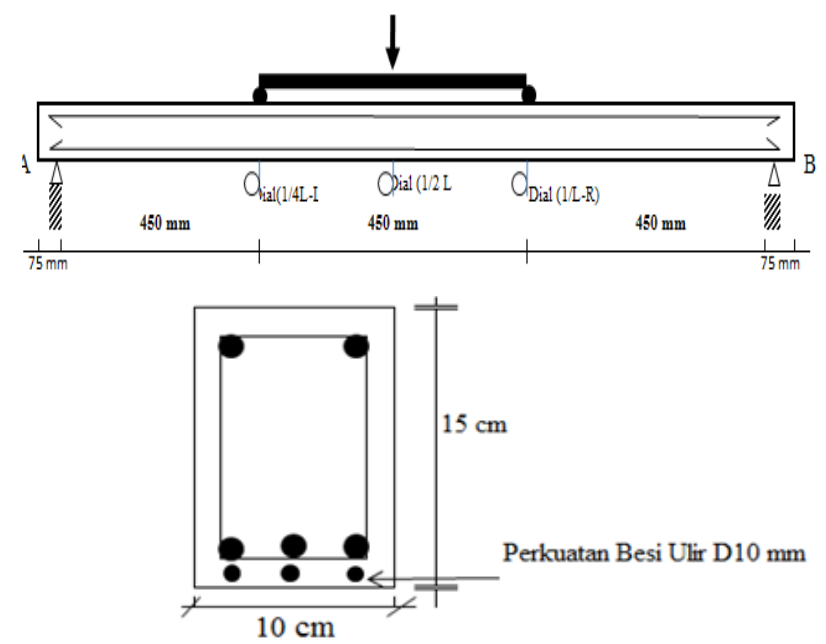

Gambar 1

Pembebanan balok dan potongan

\section{Hasil dan Pembahasan}

Setelah dilakukan analisa pada balok beton bertulang maka hasil analisa balok secara teoritis dapat dilihat pada Tabel 2.

\section{Tabel 2}

Perhitungan teoritis beban ultimit - Lendutan maksimum

\begin{tabular}{ccc}
\hline Benda Uji & $\begin{array}{c}\text { Beban Ultimit } \\
(\mathbf{K g})\end{array}$ & $\begin{array}{c}\text { Lendutan Maksimum } \\
(\mathbf{m m})\end{array}$ \\
\hline Balok Tanpa Perkuatan & $2,306.33$ & 3.9136 \\
\hline $\begin{array}{c}\text { Balok dengan Perkuatan } \\
\text { besi ulir 3D10 mm + } \\
\text { Sicadur 31 CF }\end{array}$ & $3,678.49$ & 5.6344 \\
\hline $\begin{array}{c}\text { Balok dengan Perkuatan } \\
\text { besi ulir 3D10 mm + } \\
\text { Anchor Fix 2 }\end{array}$ & $3,678.49$ & \\
\hline
\end{tabular}

Setelah dilakukan pengujian pada balok beton bertulang, maka hasil pengujian balok dapat dilihat pada Tabel 3.

Tabel 3

Hasil pengujian Beban ultimit- Lendutan maksimum

\begin{tabular}{ccc}
\hline Benda Uji & $\begin{array}{c}\text { Beban Ultimit } \\
(\mathbf{K g})\end{array}$ & $\begin{array}{c}\text { Lendutan Maksimum } \\
(\mathbf{m m})\end{array}$ \\
\hline Balok tanpa Perkuatan & $7,000.00$ & 7.2000 \\
\hline $\begin{array}{c}\text { Balok dengan Perkuatan } \\
\text { besi ulir 3D10 mm + } \\
\text { Sicadur 31 CF }\end{array}$ & $11,250.00$ & 12.5000 \\
\hline $\begin{array}{c}\text { Balok dengan Perkuatan } \\
\text { besi ulir 3D10 mm + } \\
\text { Anchor Fix 2 }\end{array}$ & $10,000.00$ & 12.4000 \\
\hline
\end{tabular}


Pengujian kuat tekan beton dilakukan di Lab. Beton Politeknik Medan benda uji terdiri dari 3 silinder dengan diameter $15 \mathrm{~cm}$ dan tinggi $30 \mathrm{~cm}$. Mutu rencana $\left(f^{\prime} c\right)$ yang dipakai adalah $25 \mathrm{MPa}$. Dari hasil pengujian mengacu pada SNI 1974: 2011 didapat mutu kuat tekanaktual sebesar 21.34 MPa. Dari slump test mengacu SNI 1972: 2008 didapat angka $11 \mathrm{~cm}$. Dari hasil pengujian kuat tarik tulangan D13 diperoleh tegangan leleh 340.21 MPa dan tegangan ultimate 533,17 MPa.

\section{Pengujian Balok Beton Tanpa Perkuatan}

Adapun grafik hubungan antara beban dan lendutan dari balok tanpa pekuatan disajikan pada Grafik 2.

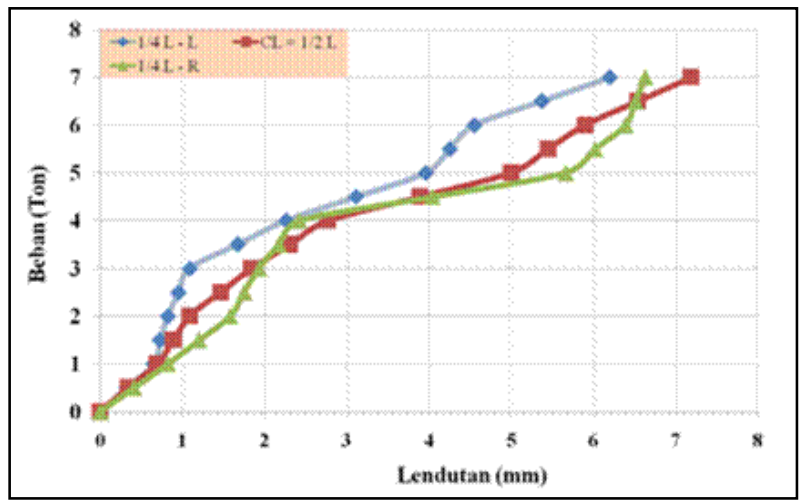

Grafik 2

Hubungan Beban-Lendutan Pada Balok Tanpa Perkuatan

Pada gambar 2 terlihat bahwa, retak pertama terjadi pada saat beban 2,0 Ton. Pada praretak, kurva dari beban defleksi masih merupakan garis lurus yang memperlihatkan perilaku elastis penuh, kemudian pada kondisi daerah 2, baja leleh terlebih dahulu yaitu pada saat beban 5,0 ton. Jika beban terus ditingkatkan, meskipun besarnya peningkatan relatif kecil akan tetapi lendutan yang terjadi cukup besar dibandingkan lendutan sebelum leleh. Akhirnya pada suatu titik tertentu beton desak mengalami rusak (pecah atau spalling) sehingga jika beban ditambah sedikit saja maka balok tidak dapat lagi menahan beban dan akhirnya runtuh. Beban batas/maskimum yang masih dapat dipikul oleh balok dengan tetap berada pada kondisi keseimbangan disebut beban batas (ultimate) ditunjukkan pada beban 7,0 Ton.

2. Pengujian Balok Beton Dengan Perkuatan Besi Ulir D.10 mm + Perekat Sikadur 31 CF Normal

Adapun grafik hubungan antara beban dan lendutan dari balok dengan pekuatan besi D13 mm memakai perekat Sikadur 31 CFnormal disajikan pada Gambar 3. 


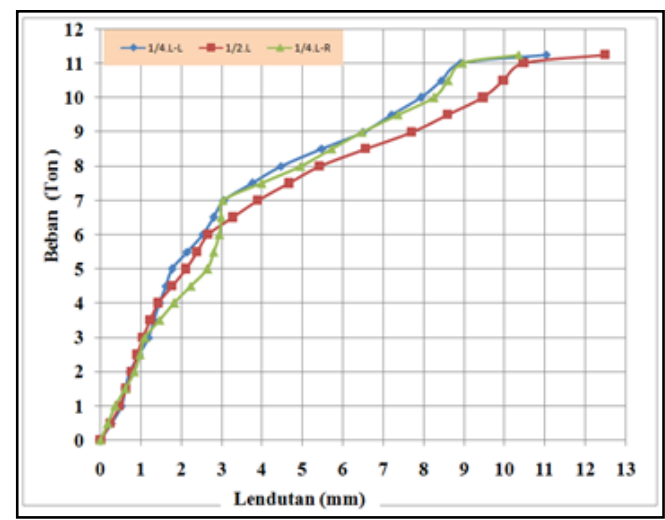

Gambar 3

Grafik Hubungan Beban-Lendutan Dengan Perkuatan Besi Ulir D.10 mm (Memakai Sikadur)

Pada gambar 3 terlihat bahwa, retak pertama terjadi pada saat beban 5,00 Ton. Pada praretak, kurva dari beban defleksi masih merupakan garis lurus yang memperlihatkan perilaku elastis penuh, kemudian pada kondisi daerah 2, baja leleh terlebih dahulu yaitu pada saat beban 7,00 Ton. Jika beban terus ditingkatkan, meskipun besarnya peningkatan relatif kecil akan tetapi lendutan yang terjadi cukup besar dibandingkan lendutan sebelum leleh. Akhirnya pada suatu titik tertentu beton desak mengalami rusak (pecah atau spalling) sehingga jika beban ditambah sedikit saja maka balok tidak dapat lagi menahan beban dan akhirnya runtuh. Beban batas/maskimum yang masih dapat dipikul oleh balok dengan tetap berada pada kondisi keseimbangan disebut beban batas (ultimate) ditunjukkan pada beban 11,25 Ton.

3. Pengujian Balok Beton Dengan Perkuatan Besi Ulir D.10 mm + Perekat Anchor Fix 2 Normal

Adapun grafik hubungan antara beban dan lendutan dari balok dengan pekuatan besi D13 mm memakai perekat anchor Fix 2 normaldisajikan pada Gambar 4.

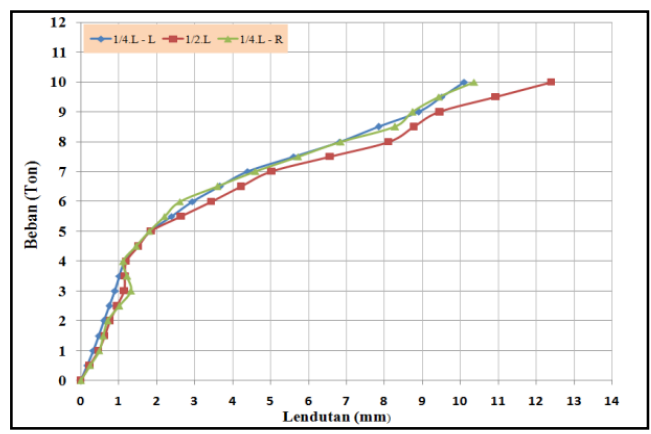

Gambar 4

Grafik Hubungan Beban-Lendutan Dengan Perkuatan Besi Ulir D.10 mm (Memakai Anchor Fix 2)

Pada gambar 4 terlihat bahwa, retak pertama terjadi pada saat beban 4,00 Ton. Pada praretak, kurva dari beban defleksi masih merupakan garis lurus yang 
memperlihatkan perilaku elastis penuh, kemudian pada kondisi daerah 2, baja leleh terlebih dahulu yaitu pada saat beban 8,00 ton. Jika beban terus ditingkatkan, meskipun besarnya peningkatan relatif kecil akan tetapi lendutan yang terjadi cukup besar dibandingkan lendutan sebelum leleh. Akhirnya pada suatu titik tertentu beton desak mengalami rusak (pecah atau spalling) sehingga jika beban ditambah sedikit saja maka balok tidak dapat lagi menahan beban dan akhirnya runtuh. Beban batas/maskimum yang masih dapat dipikul oleh balok dengan tetap berada pada kondisi keseimbangan disebut beban batas (ultimate) ditunjukkan pada beban 10 ton.

\section{Pola Retak Yang Terjadi Pada Balok Beton}

Retak lentur yang memiliki pola vertical dan diagonal, seperti yang terlihat dalam gambar 5 .

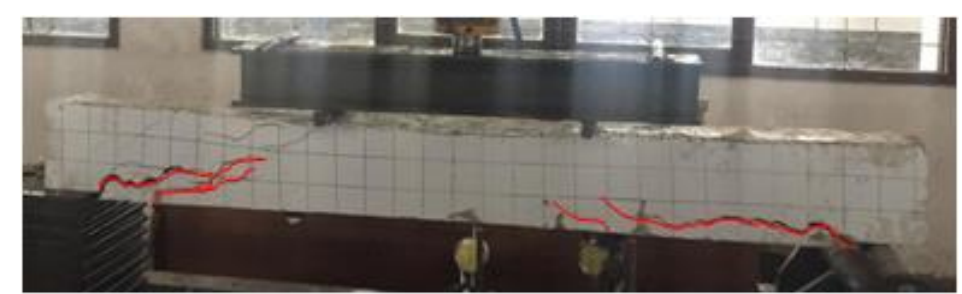

Gambar 5

\section{Pola Retak Lentur Pada Balok Tanpa Perkuatan}

Retak lentur biasanya terjadi disebabkan oleh beban yang melebihi kemampuan balok. Di mana retakan pertama yang terjadi yaitu pada saat beban 2,0 Ton, kemudian disusul dengan retakan berikutnya dengan mencapai beban ultimate yaitu 5,0 ton. Gambar di atas menunjukkan bahwa retakan yang terjadi adalah vertical/diagonal, sehingga dapat disimpulkan retak yang terjadi adalah retak lentur.

Retak yang terjadi pada perkuatan besi ulir D10 mm dengan perekat Sikadur 31 CF normal yang memiliki pola diagonal/miring, seperti yang terlihat dalam gambar 6.

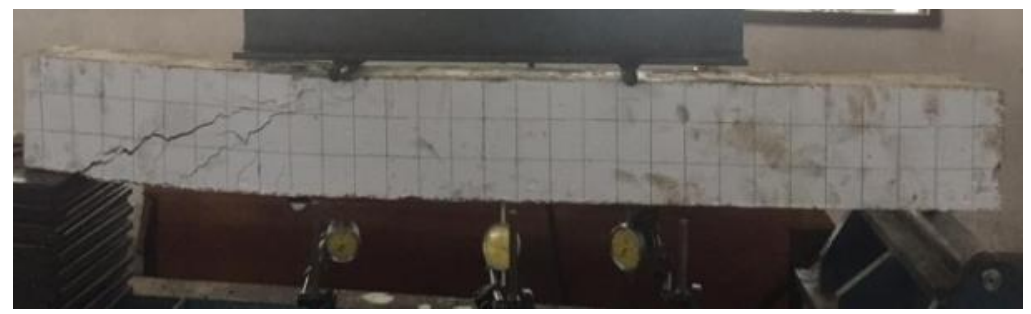

Gambar 6

\section{Pola Retak Geser di Sekitar (1/4L-R) Pada Balok Dengan Perkuatan Besi Ulir D.10 mm dan Perekat Sikadur}

Pada gambar 6 terlihat bahwa balok betonnya lemah dalam gaya tarik dari pada gaya tekan. Di mana retak pertama yang terjadi saat dibebani 5,00 ton, kemudian retak ini perlahan berubah menjadi retak diagonal. Pada saat pembebanan 7,0 Ton 
retakannya membentuk garis diagonal. Hingga beban ultimate pola retak yang terjadi adalah retak diagonal yaitu pada saat pembebanan 11,25 ton.

Retak yang terjadi pada perkuatan besi ulir D10 mm dengan perekat achor fix 2 normal yang memiliki pola diagonal/miring, seperti yang terlihat dalam gambar 7 .

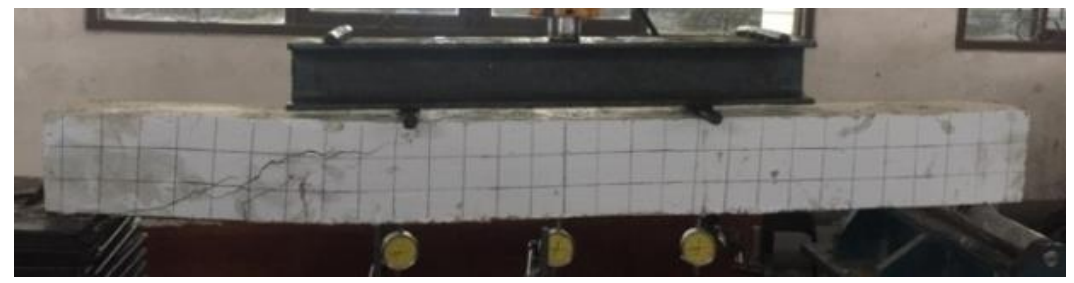

Gambar 7

Pola Retak Geser di Sekitar (1/4L-R) Pada Balok Dengan Perkuatan Besi Ulir D.10 mm dan Perekat Anchor Fix 2

Retak geser terjadi setelah adanya retak lentur yang memiliki pola vertikal. Retak geser terjadi pada balok yang menggunakan perkuatan dengan besi ulir D.10 mm dengan perekat anchor fix 2. Pada gambar di atas terlihat bahwa balok betonnya lemah dalam gaya tarik dari pada gaya tekan. Di mana retak pertama yang terjadi saat dibebani 4,00 ton, kemudian retak ini perlahan berubah menjadi retak diagonal. Dapat dilihat pada gambar di atas, pada saat pembebanan 8,0ton retakannya membentuk garis diagonal. Hingga beban ultimate pola retak yang terjadi adalah retak diagonal yaitu pada saat pembebanan 10,00 ton.

\section{Perbandingan Rekat Sikadur 31 CF Normal dan Anchor Fix 2 normal}

Perbandingan rekatan antara Sikadur $31 \mathrm{CF}$ normal dan anchor fix 2 normal dapat dilihat pada waktu uji pembebanan yakni:

a. Sikadur 31 CF Normal

Sikadur $31 \mathrm{CF}$ normal dibeban terjadi retak pertama $\mathrm{P}=5$ ton bahwa rekatan antara beton dan exposi belum ada pemisahan kedua bahan tersebut, juga pada retakan kedua $\mathrm{P}=7$ ton dan retakan ketiga $\mathrm{P}=11,25$ ton juga tidak terjadi antara beton dan exposi, artinya masih menyatu.

b. Anchor Fix 2 Normal

Sedangkan retakan antara beton awal dengan perekat anchor fix 2 juga diamati. Pada pembebanan retak pertama $\mathrm{P}=4$ ton belum ada pemisahan kedua bahan tersebut dan pada pembeban $\mathrm{P}=8$ ton juga belum terjadi pemisahan anatar beton dengan perekat, tetapi pada saat retakan ketiga pembebanan 10ton terjadi pemisahan antara beton dengan perekat anchor fix 2. Untuk lebih jelas dapat dilihat pada table perbandingan rekatan Sikadur dengan anchor fix 2. 
Analisa Balok dengan Perkuatan Penambahan Tulangan Memakai Perekat Sikadur dan Anchor Fix-2 Secara Experimental

Tabel 4

Perbandingan rekatan Sikadur dengan anchor fix 2

\begin{tabular}{|c|c|c|c|}
\hline Exposi & Umur & Pembebanan & Keterangan \\
\hline \multirow{3}{*}{$\begin{array}{l}\text { Sikadur } 31 \mathrm{CF} \\
\quad \text { Normal }\end{array}$} & \multirow{3}{*}{ diuji pada suhu $30^{\circ} \mathrm{C}$} & Retak $1=\mathrm{P}=5$ ton & Belum ada pemisahan \\
\hline & & Retak $2=\mathrm{P}=7$ ton & Belum ada pemisahan \\
\hline & & Retak $3=\mathrm{P}=11,25$ ton & Belum ada pemisahan \\
\hline \multirow{3}{*}{ Anchor fix 2 Normal } & & Retak $1=\mathrm{P}=4$ ton & Belum ada pemisahan \\
\hline & & Retak $2=\mathrm{P}=8$ ton & Belum ada pemisahan \\
\hline & $\begin{array}{c}7 \text { hari } \\
\text { diuji pada suhu } 30^{\circ} \mathrm{C}\end{array}$ & Retak $3=\mathrm{P}=10$ ton & $\begin{array}{l}\text { Terjadi pemisahan bahan beton } \\
\text { dan perekat }\end{array}$ \\
\hline
\end{tabular}

Setelah mendapatkan semua data hasil analisa teoritis maka grafik perbandingan hubungan beban - lendutan setiap sampel balok dapat dilihat pada gambar 7 .

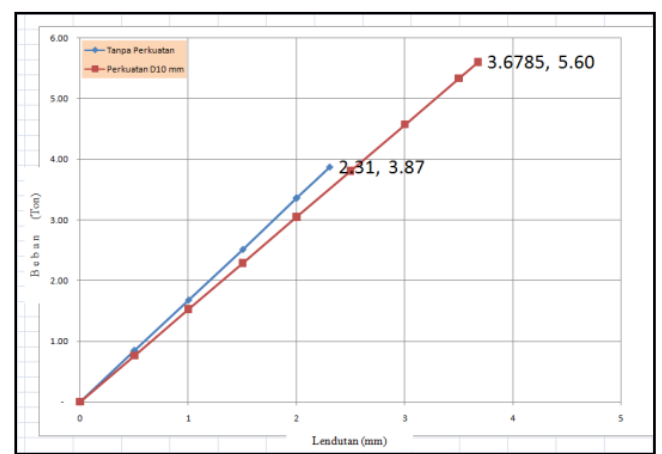

\section{Gambar 8}

\section{Grafik Perbandingan Hubungan Beban-Lendutan setiap sampel berdasarkan teori}

Dari grafik dapat dilihat bahwa secara teoritis balok normal mampu menahan beban sebesar 2,306ton dengan lendutan 3,87 mm dan setelah dilakukan penambahan perkuatan dengan besi ulir D10 mm meningkat sebesar 3,67ton dengan lendutan 5,60 mm.

Dan dari data hasil pengujian maka grafik perbandingan hubungan beban lendutan setiap sampel balok dapat dilihat pada Gambar 8 .

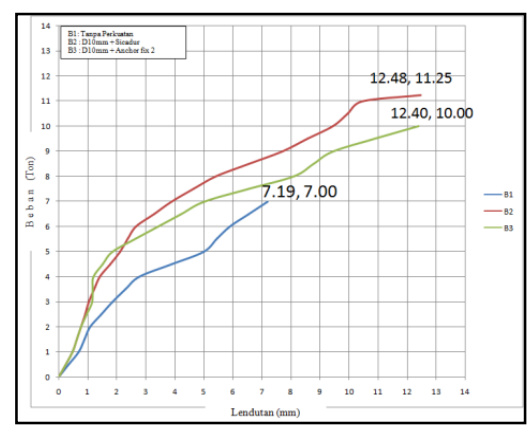

Gambar 9

Grafik Perbandingan Hubungan Beban-Lendutan setiap sampel berdasarkan pengujian 
Dari grafik 9 dapat dilihat bahwa secara eksperimen balok perkuatan dengan besi ulir D10 mm + Sikadur $31 \mathrm{CF}$ normal mampu menahan beban paling besar (baik) sebesar 12,50ton diikuti balok dengan perkuatan besi ulir D10 mm + anchor fix 2 normal sebesar 10,0 Ton dan balok tanpa perkuatan sebesar 7,0 ton. Sedangkan dilihat dari sisi lendutannya, D10+Sikadur $31 \mathrm{CF}$ normal mampu menahan lendutan paling besar yaitu 12,48 mm diikuti balok dengan D10+anchor fix 2 normal sebesar 12,40 mm dan balok tanpa perkuatan sebesr 7,20 mm. Jadi, secara teoritis Balok dengan D10+Sikadur 31 CF normal mampu menahan lendutan paling besar dibanding lainnya, serta balok dengan D10+Sikadur $31 \mathrm{CF}$ normal mampu menahan beban maksimu paling baik.

\section{Kesimpulan}

Berdasarkan hasil penelitian yang telah dilakukan dapat diambil kesimpulan sebagai berikut: 1) Berdasarkan analisa secara teoritis maupun hasil pengujian terbukti bahwa penambahan perkuatan eksternal besi ulir D10 mm memakai perekat (Sikadur 31 CF normal dan anchor fix 2 normal) mampu meningkatkan kemampuan balok dalam memikul lentur jauh lebih baik dari kondisi normalnya (tanpa perkuatan). 2) Berdasarkan analisa teoritis, pada balok tanpa perkuatan didapat beban ultimit sebesar 2,306 ton dan setelah balok perkuatan dengan besi ulir D10 $\mathrm{mm}$ dan beban ultimitnya sebesar 3,6785 ton. Dari analisa ini, peningkatan beban yang terjadi pada perkuatan besi ulir D10 mm sebesar 0,458 kali kekuatan awal. (3) Berdasarkan analisa teoritis, pada balok tanpa perkuatan didapat beban ultimit sebesar 7ton dan balok dengan perkuatan (besi ulir D10 $\mathrm{mm}$ + perekat Sikadur $31 \mathrm{CF}$ Normal) sebesar 12,25ton sedangan perkuatan (besi ulir D10 mm + anchor Fix 2 normal) sebesar 10 ton. Dari analisa ini, peningkatan beban yang terjadi pada perkuatan besi ulir D10 $\mathrm{mm}$ memakai perekat Sikadur sebesar 0,607 kali kekuatan awal sedangkan memakai perekat anchor fix 2 sebesar 0,429 kali kekuatan awal. 4) Berdasarkan hasil pengujian, balok dengan besi ulir D10 mm + Sikadur $31 \mathrm{CF}$ normal memiliki efisiensi tertinggi sebesar 37,78\% sedangkanbalok dengan besi ulir D10 mm + anchor fix 2 normal sebesar $30 \%$. 5) pola retak pada pengujian tanpa perkuatan terjadi retak pada pembeban $\mathrm{P}=2$ ton sedangkan dengan perkuatan besi ulir D10 mm menggunakan perekat sikadur $31 \mathrm{CF}$ normal terjadi retak pada $\mathrm{P}=5$ ton dan Menggunakan perekat anchor fix 2 normal terjadi retak pada $\mathrm{P}$ $=4$ ton. 6) Perbandingan rekatan antara Sikadur $31 \mathrm{CF}$ normal lebih unggu atau lebih kuat rekatannya dari rekatan anchor fix 2 normal. 
Analisa Balok dengan Perkuatan Penambahan Tulangan Memakai Perekat Sikadur dan Anchor Fix-2 Secara Experimental

\section{BIBLIOGRAFI}

Djamaluddin, R., Irmawati, R., \& Didipu, N. L. (2014). Pengaruh Lapisan Hybrid Serat Karbon dan Serat Gelas terhadap Kapasitas Lentur Balok Beton Bertulang. Universitas Hassanudin.

Ginardi, Ireneus Petrico, Anggraini, Retno, \& Suseno, Hendro. (2014). Perbandingan Kekuatan Lentur Balok Beton Bertulang Dengan Menggunakan Perkuatan CFRP dan GFRP. Jurnal Mahasiswa Jurusan Teknik Sipil, 1(2), pp-250.

Helmi, Masdar. (2009). Perbaikan Balok Beton Bertulang Yang Telah Mengalami Beban Puncak Dengan Baja Siku. Rekayasa: Jurnal Ilmiah Fakultas Teknik Universitas Lampung, 13(1), 58-69.

Isneini, Mohd. (2009). Kerusakan dan Perkuatan Struktur Beton Bertulang. Rekayasa: Jurnal Ilmiah Fakultas Teknik Universitas Lampung, 13(3), 259-270.

Jamal, Atika Ulfah, Bale, Helmy Akbar, \& Haqiqi, Iqbal. (2015). Perilaku Lentur Perbaikan Balok Beton Bertulang Dengan Variasi Lebar Carbon Fibre Reinforced Polymer. Teknisia, 20(2), 154-162.

Jaya, Budianto. (2014). Analisa Balok Beton Bertulang Cold Formed Menggunakan Solidworks. Sriwijaya University.

Mardiah, Ainul, Satriana, Dwi Puspita, \& Syahriati, Elida. (2017). Peranan dukungan sosial dalam mencegah kekerasan dalam pacaran: studi korelasi pada remaja di Jakarta. Jurnal Psikologi Ulayat: Indonesian Journal of Indigenous Psychology, 4(1), 29-42.

Mulyadi, Mulyadi. (2018). Pengaruh Penggunaan Carbon Fibre Sheet Terhadap Kekakuan Pada Balok Beton Bertulang. Genta Mulia: Jurnal Ilmiah Pendidikan, 9(1).

Nur, Oscar Fitrah. (2009). Kajian Eksperimental Perilaku Balok Beton Tulangan Tunggal Berdasarkan Tipe Keruntuhan Balok. Jurnal Rekayasa Sipil (JRS-Unand), 5(2), 39-52.

Pangestuti, Endah Kanti. (2009). Penggunaan Carbon Fiber Reinforced Plate Sebagai Bahan Komposit Eksternal Pada Struktur Balok Beton Bertulang. Universitas Sebelas Maret.

Puspita, Fiany Fajar, Aulia, Teuku Budi, \& Afifuddin, Mochammad. (2018). Analisis Retak Lentur Pada Balok Beton Bertulang Mutu Tinggi Yang Diperbaiki Dengan Injeksi Epoxy. Jurnal Teknik Sipil, 1(4), 831-844.

Rosyidah, Anis, \& Yasin, Efendi. (2011). Tinjauan Variasi Tebal Grouting Sikadur® 31 Cf Normal Dan Panjang Penyaluran Terhadap Daya Lekat Baja Tulangan Pada Beton Mutu Normal. Jurnal Poli-Teknologi, 10(1). 
Andar Sitohang, Johannes Tarigan dan Medis Surbakti

Sudarsana, I. Ketut, \& Widiarsa, Ida Bagus Rai. (2008). Perilaku runtuh balok beton bertulang yang diperkuat dengan lapis glass fibre reinforced polymer (GFRP). Jurnal Ilmiah Teknik Sipil.

Susanto, Ambar, Kasyanto, Heri, \& Susilahadi, Susilahadi. (2018). Studi Perkuatan Balok Beton Bertulang Dengan Strand Tanpa Penegangan Dan Tulangan U. Jurnal Poli-Teknologi, 17(1).

Utami, Sri Rejeki Laku, Nuroji, Nuroji, \& Antonius, Antonius. (2016). Pengaruh Pembalutan Carbon Fiber Wrap (CFW) Terhadap Daktilitas Balok Beton Bertulang. INformasi Dan Ekspose Hasil Riset Teknik SIpil Dan Arsitektur, 12(2), 140-155. 